\title{
SDG 16: PEACE, JUSTICE AND STRONG INSTITUTIONS
}

\author{
Sabine Corneloup and Jinske Verhellen
}

Goal 16: Promote peaceful and inclusive societies for sustainable development, provide access to justice for all and build effective, accountable and inclusive institutions at all levels

16.1 Significantly reduce all forms of violence and related death rates everywhere

16.2 End abuse, exploitation, trafficking and all forms of violence against and torture of children

16.3 Promote the rule of law at the national and international levels and ensure equal access to justice for all

16.4 By 2030, significantly reduce illicit financial and arms flows, strengthen the recovery and return of stolen assets and combat all forms of organized crime

16.5 Substantially reduce corruption and bribery in all their forms

16.6 Develop effective, accountable and transparent institutions at all levels

16.7 Ensure responsive, inclusive, participatory and representative decision-making at all levels

16.8 Broaden and strengthen the participation of developing countries in the institutions of global governance

16.9 By 2030, provide legal identity for all, including birth registration

16.10 Ensure public access to information and protect fundamental freedoms, in accordance with national legislation and international agreements

16.a Strengthen relevant national institutions, including through international cooperation, for building capacity at all levels, in particular in developing countries, to prevent violence and combat terrorism and crime

16.b Promote and enforce non-discriminatory laws and policies for sustainable development

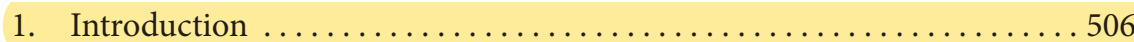

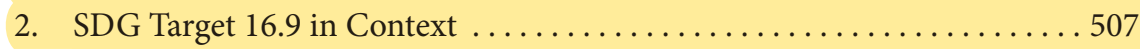

2.1. Legal Identity within SDG 16 as a Whole............... 507

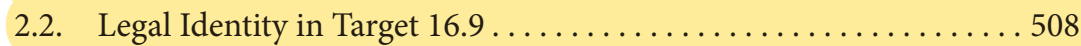


Sabine Corneloup and Jinske Verhellen

2.3. Legal Identity in a Migration Context: The Role of Private International Law .............................. 511

2.4. Overview and Assessment of Implementation Initiatives ....... . 514

2.4.1. Developments within the United Nations: UN Legal Identity Agenda. ............................... 514

2.4.2. Public-Private Partnerships ................. 516

3. Survey of Existing Private International Law Methods and Techniques on Legal Identity . . . . . . . . . . . . . . . . . . . . . . . . . . 520

3.1. Legal Identity in International Conventions and EU Regulations on Private International Law . . . . . . . . . . . . . . . . 520

3.1.1. European Union ........................ 520

3.1.2. International Commission on Civil Status ........... 521

3.1.3. Hague Conference on Private International Law ......... 522

3.2. Legal Identity at the National Private International Law Level . . . . 525

3.2.1. Private International Law Assumptions and Objectives . . . . 525

3.2.2. Private International Law Methods and Techniques ...... . 526

3.2.2.1. The Rise of Evidentiary Issues in Migration-Related Situations.......................... . 527

3.2.2.2. Validity of the Legal Situation of a Person ....... 528

3.2.2.2.1. General Private International Law Methods and Techniques......... 528

3.2.2.2.2. Fraud-Related Provisions on Sham Legal Relationships............. 530

3.2.2.3. Proof of the Legal Situation of a Person ......... 531

3.2.2.3.1. Foreign Civil Status Acts .......... 531

3.2.2.3.2. Supplementary Judgments ........ 533

3.2.2.3.3. Age Assessment and DNA Testing ..... 533

4. Potential of the SDG Framework to Spur New Thinking on Legal Identity in Private International Law . . . . . . . . . . . . . . 535

4.1. Overcoming the Public/Private Law Divide in Order to Effectively Address Legal Identity .................... 535

4.2. Revitalising and Building on International Conventions

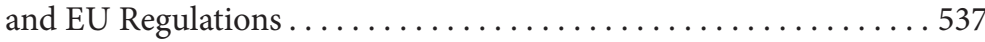

4.3. Disconnecting Migration Policies from Legal Identity Issues . . . . . 538

5. Conclusion ...................................... 539

\section{INTRODUCTION}

This chapter focuses on Target 16.9 of the Sustainable Development Goals (SDGs), which states: 'By 2030, provide legal identity for all, including birth 
registration.' It is a tentative attempt to explore the reciprocal influences between private international law and this SDG target.

In section 2, Target 16.9 is briefly positioned within the context of SDG 16 as a whole, before being presented in itself, as well as in the context of global migration, which also brings other SDGs into the picture and highlights the link to private international law. Section 2 ends with an overview of some initiatives that have been undertaken, within the United Nations agencies and in collaboration with the private sector, to support SDG Target 16.9.

In section 3, existing private international law instruments, methods and techniques on legal identity and their relevance in a migration context are assessed. A survey of international conventions and EU regulations on private international law will reveal that none of the existing instruments plays a prominent role, if any, in a migration context. At the national level, existing private international law methods and techniques on legal identity are assessed from the perspective of states of destination or states of transit as only then a cross-border element arises activating private international law. The use of the terms 'states of destination', 'states of transit' and 'states of origin' reflects a focus on Global South to Global North migration. We are adopting a European perspective and must draw attention to the limits such an approach inevitably entails.

Section 4 is an attempt to somehow overcome this limitation by also including the perspective of states of origin in the Global South. It addresses the question whether the evolving new global framework in line with SDG Target 16.9 could improve the situation in the states of origin by promoting and implementing birth registration and consequently spur new thinking on legal identity matters in private international law.

\section{SDG TARGET 16.9 IN CONTEXT}

\subsection{LEGAL IDENTITY WITHIN SDG 16 AS A WHOLE}

SDG 16 ('Peace, Justice and Strong Institutions') aims to promote peaceful and inclusive societies for sustainable development, provide access to justice for all and build effective, accountable and inclusive institutions at all levels. Very comprehensive in its definition, SDG 16 relies on 12 specific targets, and its implementation is measured by 23 indicators.

Among the different targets, many interdependences and interrelations exist. Target 16.3 on the rule of law and access to justice is particularly cross-cutting. As it is fundamental to most of the chapters of this book, it is addressed from the perspective of the specific SDGs developed there. 
Similarly, Target 16.9 on legal identity is key to advance other targets, within SDG 16 and beyond. The general goal of 'justice' and the specific targets of 'the rule of law' and 'access to justice' (Target 16.3), the protection of fundamental freedoms (Target 16.10) and the enforcement of non-discriminatory laws and policies (Target 16.b) cannot be addressed without providing legal identity for all. Legal identity is the gateway to the world of law and justice. Birth registration plays a primary role in ensuring individual rights and access to justice.

Likewise, there is an interdependence between the Targets 16.2 and 16.9. The target of ending child trafficking and all forms of violence against children is difficult to achieve when the victims of trafficking and violence do not have a legal identity/existence.

In turn, Target 16.9 cannot be reached without the possibility of relying on 'strong institutions' and the further development of effective, accountable and transparent institutions (Target 16.6) responsible for the registration, certification and acceptance of basic characteristics of an individual's identity. As many developing countries currently do not meet the objective of providing legal identity for all, their participation in international organisations must be strengthened (Target 16.8). ${ }^{1}$

Moreover, Target 16.9 is not only the vital foundation of SDG 16, but as pointed out by the UN Legal Identity Expert Group ${ }^{2}$ - 'legal identity is widely acknowledged to be catalytic for achieving at least ten of the Sustainable Development Goals (SDGs). Data generated from civil registration and population registers support the measurement of over 60 SDG indicators.'3

Hence, there are ample reasons to focus on the specific, but fundamental and wide-ranging, SDG Target 16.9.

\subsection{LEGAL IDENTITY IN TARGET 16.9}

According to the United Nations Legal Identity Agenda, SDG Target 16.9 'is key to advance the 2030 Agenda commitment to leave no one behind.' ${ }^{4}$

SDG Target 16.9 holds great promise: the promise of really implementing the fundamental right of everyone to be recognised as a person before the law. This fundamental right to a legal identity, as enshrined in Article 6 of the Universal Declaration on Human Rights and Article 16 of the International Covenant on Civil and Political Rights, is a prerequisite for exercising all other rights.

See infra section 4.1

See infra section 2.4 .

UN Legal Identity Expert Group, 'United Nations Strategy for Legal Identity for All', para 5 <ttps://unstats.un.org/legal-identity-agenda/documents/UN-Strategy-for-LIA.pdf> accessed 15 April 2021.

4 'United Nations Legal Identity Agenda' <https://unstats.un.org/legal-identity-agenda> accessed 15 April 2021. 
Providing legal identity for all presupposes an official trace of this identity, starting with registration at the time of birth. This is reflected in the current United Nations Operational Definition of the concept of legal identity ${ }^{5}$ as:

the basic characteristics of an individual's identity, e.g. name, sex, place and date of birth conferred through registration and the issuance of a certificate by an authorized civil registration authority following the occurrence of birth. In the absence of birth registration, legal identity may be conferred by a legally-recognized identification authority. This system should be linked to the civil registration system to ensure a holistic approach to legal identity from birth to death. Legal identity is retired by the issuance of a death certificate by the civil registration authority upon registration of death. ${ }^{6}$

Without registration of their legal identity people are invisible in the eyes of the law: '[f] or people to count, they must first be counted.'

Birth registration is a fundamental right, recognised by Article 24(2) of the International Covenant on Civil and Political Rights and Article 7 of the Convention on the Rights of the Child. For SDG Target 16.9, one concrete indicator has been formulated: 'Proportion of children under 5 years of age whose births have been registered with a civil authority, by age.' Birth registration is often seen as the first right of the child, as it is the gateway to legal identity, the port of entry into the world of law. Through birth registration, the child's legal existence and identity is established, which is a prerequisite for exercising all other rights. Without birth registration, children may be denied basic rights, such as health, education and social welfare. ${ }^{8}$ They are more vulnerable to violence and exploitation, for instance when proof of age is needed to help prevent child labour and child marriage. A birth certificate can also help protect children against family separation, trafficking, illegal adoption and the risk of statelessness. ${ }^{9}$ Yet UNICEF recalls that the births of one quarter of children under the age of five worldwide (or 166 million children) have never been

ibid.

UN Legal Identity Expert Group, 'United Nations Strategy for Legal Identity for All' $<$ https://unstats.un.org/legal-identity-agenda/documents/UN-Strategy-for-LIA.pdf > accessed 15 April 2021.

7 Plan International, 'Birth registration' < https://plan-international.org/early-childhood/ birth-registration> accessed 15 April 2021.

8 UN Committee on the Rights of the Child, General Comment No 7 (early childhood), UN Doc CRC/C/GC/7/Rev (20 September 2006) para 25.

9 UN Committee on the Protection of the Rights of All Migrant Workers and Members of Their Families, Joint General Comment No 4 (2017) of the Committee on the Protection of the Rights of All Migrant Workers and Members of Their Families and No 23 (2017) of the Committee on the Rights of the Child on State obligations regarding the human rights of children in the context of international migration in countries of origin, transit, destination and return, UN Doc CMW/C/GC/4-CRC/C/GC/23 (16 November 2017) para 20. 
officially recorded. ${ }^{10}$ Fewer than half (46 per cent) of all children under the age of five in sub-Saharan Africa have had their births registered. ${ }^{11}$

Legal identity is much broader than birth registration only. It covers all aspects of one's personal status: age, name, gender, marital status, etc. Article 7 of the Convention on the Rights of the Child, for instance, links birth registration to the right from birth to a name and a nationality. Often, several aspects of personal status are interrelated. For instance, in some countries parents will have to present a marriage certificate before a birth certificate for their child can be issued, or a mother may face gender discrimination when she tries to register her child if she does not have a marriage certificate. ${ }^{12}$ Therefore, promoting SDG Target 16.9 requires new governance practices which include 'ensuring the proper and universal registration of the occurrence of all vital events (births, deaths, marriages, divorces ...), issuance of certificates that serve as legal tenders and introduce the lifetime legal identity of the individual and the production of comprehensive, regular and reliable vital statistics based on universal civil registration of vital events. ${ }^{13}$ Concerned by the fact that the coverage of civil registration is not universal and complete in all countries of the world, the 2030 Agenda for Sustainable Development set as indicator 17.19.2: 'proportion of countries that have achieved 100 per cent birth registration and 80 per cent death registration'.

Legal identity requires not only the registration of all major life events, but also their certification. UNICEF reports on the large gap between the number of children whose births are reported as registered and those who actually have a birth certificate. ${ }^{14}$ According to Plan International, globally, an estimated one billion people cannot officially prove their identity and 47 per cent of those are children without a birth certificate. ${ }^{15}$ There is still a huge discrepancy between

10 See UNICEF, 'Birth registration' (June 2020) <https://data.unicef.org/topic/child-protection/ birth-registration> accessed 15 April 2021. See also UN Department of Economic and Social Affairs, 'Goal 16'<https://sustainabledevelopment.un.org/sdg16> accessed 15 April 2021; UN Economic and Social Council, 'Special edition: progress towards the Sustainable Development Goals. Report of the Secretary-General' (8 May 2019) UN Doc E/2019/68, para 37: 'Even if many regions have reached universal or near universal birth registration, globally the average is just 73 per cent.'

11 See UN Department of Economic and Social Affairs, 'Goal 16' < https://sustainabledevelopment. un.org/sdg16> accessed 15 April 2021.

12 UNICEF, 'What is birth registration and why does it matter?' < www.unicef.org/stories/whatbirth-registration-and-why-does-it-matter> accessed 15 April 2021.

13 UN Legal Identity Expert Group, 'United Nations Strategy for Legal Identity for All' para $6<$ https://unstats.un.org/legal-identity-agenda/documents/UN-Strategy-for-LIA.pdf> accessed 15 April 2021.

14 Of the roughly 508 million children under the age of five who are registered worldwide, about 70 million lack proof of registration in the form of a birth certificate, See UNICEF, 'Birth Registration for Every Child by 2030: Are we on track?' <https://data.unicef.org/ resources/birth-registration-for-every-child-by-2030> accessed 15 April 2021.

15 Plan International, 'Birth registration' <https://plan-international.org/early-childhood/ birth-registration> accessed 15 April 2021. 
legal identity and proof of legal identity. ${ }^{16}$ The right to be recognised as a person before the law often remains meaningless when the person concerned has no documentary evidence (civil registry certificate, identity card and/or passport) or, as we will discuss in section 3 , when this proof of legal identity is questioned.

\subsection{LEGAL IDENTITY IN A MIGRATION CONTEXT: THE ROLE OF PRIVATE INTERNATIONAL LAW}

At the global (read: United Nations) level there is currently a political will to address legal identity issues from a human rights perspective, including in a migration context. The 2030 Agenda for Sustainable Development, and more specifically SDG Target 10.7, includes migration in its global framework. International migration requires international cooperation 'to ensure safe, orderly and regular migration, involving full respect for human rights and the humane treatment of migrants regardless of migration status, of refugees and of displaced persons. ${ }^{17}$

SDG 16 also has a clear link with migration, as shown by the SDGs Report 2019:

Realizing the goal of peaceful, just and inclusive societies is still a long way off. ... In 2018, the number of people fleeing war, persecution and conflict exceeded 70 million, the highest level that the United Nations High Commissioner for Refugees has seen in almost 70 years. All are particularly vulnerable to various forms of abuse, including trafficking, violence and non-inclusive decision-making. Ensuring that they receive adequate protection is paramount to achieving the goal of inclusive societies and sustainable development. ${ }^{18}$

The latest figures for 2019 are even worse, and according to the UNHCR forced displacement nowadays is not only vastly more widespread but is simply no longer a short-term and temporary phenomenon. ${ }^{19}$

16 The latter is defined by the UN Legal Identity Expert Group as 'a credential, such as birth certificate, identity card or digital identity credential that is recognized as proof of legal identity under national law and in accordance with emerging international norms and principles'; see UN Legal Identity Expert Group, 'United Nations Strategy for Legal Identity for All' para $15<$ https://unstats.un.org/legal-identity-agenda/documents/UN-Strategy-for-LIA. pdf $>$ accessed 15 April 2021.

17 UNGS Res 70/1, UN Doc A/RES/70/1 (25 September 2015) para 29.

18 See UN, 'The Sustainable Development Goals Report 2019' (2019) <https://unstats.un.org/ sdgs/report/2019> accessed 15 April 2021.

19 UNHCR, 'Global Trends. Forced displacement in 2019' <www.unhcr.org/globaltrends2019/> accessed 15 April 2021: 79.5 million forcibly displaced persons worldwide, the highest number ever reported by the UNHCR. 
SDG Target 16.9 should be read together with the UN Global Compact on Refugees ${ }^{20}$ and the UN Global Compact for Migration. ${ }^{21}$ The Global Compact on Refugees (para 82) refers to civil and birth registration as a major tool for protection. While it does not necessarily lead to conferral of nationality, birth registration helps establish legal identity and prevent the risk of statelessness. Timely access to civil and birth registration and documentation should be facilitated for refugees and stateless persons. States are primarily responsible for providing proof of legal identity to refugees and stateless persons, but may be supported by UNHCR. ${ }^{22}$ The Global Compact for Migration (Objective 4, para 20) commits 'to fulfil the right of all individuals to a legal identity by providing all ... nationals with proof of nationality and relevant documentation, allowing national and local authorities to ascertain a migrant's legal identity' and 'to ensure ... that migrants are issued adequate documentation and civil registry documents, such as birth, marriage and death certificates, at all stages of migration, as a means to empower migrants to effectively exercise their human rights'.

Providing (proof of) legal identity for all gives rise to private law issues. For instance, is an Afghan youngster an unaccompanied minor? Is a marriage a child marriage? How can a Pakistani couple prove their religious Ahmadi marriage? How does a Syrian man prove that a child is his when the child was born in a Turkish refugee camp and there is no birth certificate? In a migration context, these private law issues are inherently cross-border ones, which bring us to the field of private international law. The cross-border circulation and acceptance of documents that record the legal identity of people traditionally belongs to the field of private international law, which strives for as much cross-border continuity of people's legal identity as possible. For many refugees and migrants, this fundamental private international law objective is currently not being achieved, due to the lack of reliable documentary evidence. Refugees and migrants often face huge challenges in proving their legal identity. ${ }^{23}$ Civil registry systems may be destroyed by war or simply not exist, and even where they do exist, people may, for various reasons - be it geographic distance, or the absence or corruption of official authorities - be unable to contact official authorities at the moment of birth, marriage or death. However, even where an

20 The resolution on the Office of the United Nations High Commissioner for Refugees which affirms the global compact on refugees was adopted by the General Assembly on 17 December 2018, UN Doc A/RES/73/151, Final Draft (June 2018) <www.unhcr.org/ events/conferences/5b3295167/official-version-final-draft-global-compact-refugees.html> accessed 15 April 2021.

21 Adopted on 10 December 2018: UN, 'Global compact for migration' < https://refugeesmigrants. un.org/migration-compact> accessed on 15 April 2021.

22 UN, 'Implementation of the United Nations Legal Identity Agenda: United Nations Country Team Operational Guidelines', para 66 <https://unstats.un.org/legal-identity-agenda/ documents/UNCT_Guidelines.pdf $>$ accessed 15 April 2021.

23 See more in detail Jinske Verhellen, 'Cross-Border Portability of Refugees' Personal Status' (2018) 31 Journal of Refugee Studies 427. 
institutional framework for universal birth registration is in place, officials may refuse to register the birth of migrant children, whether the parent's migratory situation is regular or not. ${ }^{24}$ Moreover, those fleeing from war, persecution or poverty may leave documents behind or lose them during their journey (because they are confiscated by smugglers, for instance).

States of destination for migrants usually are accustomed to, and sometimes obsessed with, dates and documents. By contrast, in many countries of origin, people do not need official identity documents for their daily life. Sometimes they do not know their exact age. Major family life events, such as marriage, succession or the passing on of family names to children, are organised according to customary practices, without public authorities being directly involved. When an official document is required for access to specific services and activities, like education (in particular for the participation in national exams) or healthcare, documents such as the Afghan tazkera, for instance, despite being easily falsified, are considered sufficient. As will be discussed later, this reality in many States of origin does not correspond to the fundamental assumptions on which private international law relies. The post-colonial heritage sometimes strengthens that gap. In some post-colonial states, indeed, people perceive civil registration systems, which generally were built by the colonial state, as a symbol of survival of colonial domination, and therefore are reluctant to register major life events.

The purpose of this chapter is to bring the private side of legal identity into focus, or the objective of guaranteeing cross-border continuity of personal and family status, which can be considered 'an emerging human rights imperative in itself'. ${ }^{25}$

As will become clear in section 3, the current focus on combating irregular migration, as well as on police and security considerations, risks depriving SDG Target 16.9 of its very purpose by diverting attention from the rights and needs of human beings. Therefore, we will adopt a private law perspective as this implies a focus on migrants as individuals rather than on the state's interests. ${ }^{26}$ States often focus on ideas of burden-sharing and fraud prevention. They manage international migration from a very distant and even statistical perspective (flows of people and figures), whereas consideration of the interests

24 See UN Committee on the Protection of the Rights of All Migrant Workers and Members of Their Families, Joint General Comment No 4 (2017) of the Committee on the Protection of the Rights of All Migrant Workers and Members of Their Families and No 23 (2017) of the Committee on the Rights of the Child on State obligations regarding the human rights of children in the context of international migration in countries of origin, transit, destination and return', UN Doc CMW/C/GC/4-CRC/C/GC/23 (16 November 2017) para 20.

25 Hans van Loon, 'The present and prospective contribution of global private international law unification to global legal ordering' in Franco Ferrari and Diego P Fernández Arroyo (eds), Private International Law. Contemporary Challenges and Continuing Relevance (Edward Elgar Publishing 2019) 228.

26 Sabine Corneloup, 'Can Private International Law Contribute to Global Migration Governance’ in Horatia Muir Watt and Diego P Fernández Arroyo (eds), Private International Law and Global Governance (OUP 2014) 302. 
of migrants and their family members requires a more engaged approach. Such a private law perspective does not necessarily mean that public law is taboo. Legal identity is a complex notion at the crossroads of public and private law: ' $\mathrm{t}$ ] he need to contribute to the development of the global commons cannot stop at the boundaries of private or public law. ${ }^{27}$

\subsection{OVERVIEW AND ASSESSMENT OF IMPLEMENTATION INITIATIVES}

Since the adoption of the SDGs, a significant number of initiatives have already been undertaken to support Target 16.9. The following overview will show their strong ambitions, as well as the concerns some of them are raising.

\subsubsection{Developments within the United Nations: UN Legal Identity Agenda}

As the issue of legal identity for all is of paramount importance in terms of fulfilling the SDG Agenda, the UN Legal Identity Expert Group (UN LIEG) was established in September 2018. ${ }^{28}$ The substantive focus of the UN LIEG is an emphasis on building legal identity systems founded on civil registration from birth to death, and with a human rights approach. ${ }^{29}$ In December 2019 the UN LIEG transitioned into the United Nations Legal Identity Task Force. This Task Force has to convene all United Nations agencies whose mandate is directly or indirectly linked with the holistic approach to legal identity. On civil registration (birth, death, marriage, divorce, adoption), for instance, these are UNICEF, the World Health Organization (WHO), the UN High Commissioner for Refugees (UNHCR), the International Organization for Migration (IOM), the UN Population Fund, and the UN Entity for Gender Equality and the Empowerment of Women. The Task Force also needs to involve other organisations outside the United Nations, such as the World Bank, the African, Asian and Inter-American Development Bank, and Plan International. ${ }^{30}$

27 Verónica Ruiz Abou-Nigm, 'Unlocking private international law's potential in global (migration) governance' in Franco Ferrari and Diego P Fernández Arroyo (eds), Private International Law. Contemporary Challenges and Continuing Relevance (Edward Elgar Publishing 2019) 208.

28 The LIEG is co-chaired by the Department of Economic and Social Affairs of the UN Secretariat (DESA), the UN Development Programme (UNDP) and the UN Children's Fund (UNICEF).

29 UN Legal Identity Expert Group, 'United Nations Strategy for Legal Identity for All' <https://unstats.un.org/legal-identity-agenda/documents/UN-Strategy-for-LIA.pdf> accessed 15 April 2021. See also <https://unstats.un.org/legal-identity-agenda/LIEG> accessed 15 April 2021.

30 UN, 'Implementation of the United Nations Legal Identity Agenda: United Nations Country Team Operational Guidelines' paras 184-186<https://unstats.un.org/legal-identity-agenda/ documents/UNCT_Guidelines.pdf $>$ accessed 15 April 2021. 
Within this UN LIEG framework, the United Nations Legal Identity Agenda (UN LIA) 2020-2030 has been defined. The UN LIA calls on all Member States to ensure universal civil registration of all vital events, rendered into regular, reliable and comprehensive vital statistics, and resulting in legal identity for all. ${ }^{31}$ A recent UN report on the implementation of the UN LIA refers to the role of several UN agencies in the field of birth registration, such as UNICEF, the UNHCR, the IOM, the WHO and the UN Population Fund. ${ }^{32}$

A recent report by UNICEF shows that investments to increase birth registration levels have begun to yield results. But it also shows that much more effort is needed to reach the goal of universal birth registration and to improve civil registries to the point where such gains are irreversible. ${ }^{33}$ Hence, UNICEF calls for further actions. ${ }^{34}$

The UNHCR supports states in the registration of refugees and facilitates access to civil registration and documentation for refugees and stateless persons. While it does not necessarily lead to conferral of nationality, birth registration helps establish legal identity and prevent the risk of statelessness. The UNHCR's Global Action Plan to End Statelessness 2014-2024 contains actions that explicitly refer to the importance of legal identity for the prevention of statelessness. ${ }^{35}$

Implementing SDG Target 16.9 also includes special procedures for migrants. The IOM is primarily concerned with migrants located in other countries

\section{$31 \quad$ ibid para 8.}

32 ibid paras $153-174$.

33 UNICEF, 'Birth Registration for Every Child by 2030: Are we on track?' $34<$ https://data. unicef.org/resources/birth-registration-for-every-child-by-2030> accessed 15 April 2021.

34 UNICEF calls for five actions to protect all children, starting from birth. First, every child should be provided with a certificate following birth registration. Second, all parents, regardless of gender, should be empowered to register their children at birth. Third, birth registration should be linked to social services (health, social protection and education). The WHO and UNICEF emphasise, for instance, the cooperation between civil registration and health systems. They encourage the notification of births and deaths directly to civil registrars. Fourth, investments in safe and innovative technological solutions is needed to facilitate birth registration. Technology can be used to obtain timely, accurate and permanent records. For example, the use of mobile communications technologies, including cell phones, can help reach unregistered children by minimising the distance and related travel costs for remote populations. Fifth, communities should be engaged to demand birth registration for every child. To create effective, sustainable change, community members - particularly parents and community leaders - must understand how and why birth registration benefits their families. See UNICEF, 'Birth Registration for Every Child by 2030: Are we on track?' $35<$ https://data. unicef.org/resources/birth-registration-for-every-child-by-2030> accessed 15 April 2021; UNICEF and Inter-American Development Bank, Towards Universal Birth Registration. A Systemic Approach to the Application of ICT (2015).

35 See UNHCR, 'Global Action Plan to End Statelessness: 2014-2024' <www.unhcr.org/ibelong/ global-action-plan-2014-2024> accessed 15 April 2021: Action 7 urges states to ensure birth registration for the prevention of statelessness and sets out how states can implement this action including through procedures for late and delayed birth registration and campaigns to register older children and adults. Action 8 calls on states to issue nationality documentation to those who are entitled to it, ensuring that procedures to obtain such documentation are accessible, affordable and implemented in a non-discriminatory way. 
without documentation. In order to assist migrants in obtaining civil status documents, which are critical for obtaining travel documentation, the IOM often works closely with consular authorities. The IOM also assists migrants with registering their children at birth. It has been looking into possibilities to develop more activities allowing for birth registration of children of migrants, through facilitation of access to consular authorities.

In addition, the UN Global Compact for Migration (Objective 4) mentions seven different and ambitious actions to realise the objective to fulfil the right to a legal identity by providing everyone with proper civil registry documents as a means to empower migrants to effectively exercise their human rights.

All these action plans within the framework of the United Nations are ambitious. They reflect the pursuit of universal birth registration, including the actual issuance of a birth certificate to all - and this not only at the time of birth, but also at later points in time. These action plans, however, also raise concerns. Initiatives implementing SDG Target 16.9 often focus on registration and certification of vital life events according to a public/administrative law understanding of legal identity. The civil registration apparatus is often considered from the angle of collecting statistical data. Comprehensive vital statistics are indeed of crucial importance for governments and UN agencies in order not only to implement SDG Target 16.9, but also to monitor public funding for several other SDGs. However, the essential objective of civil registration involves more than statistics. Above all, it provides individuals with the legal confirmation of a vital life event and the issuance of a legal document. As said above, this official trace of a person's existence is the entry point to the exercise of human rights, in the state of origin but also in a migration context.

\subsubsection{Public-Private Partnerships}

Several SDGs' implementation initiatives rely on public--private partnerships. Such collaboration with the private sector includes both not-for-profit and profit-making entities.

Several initiatives of Plan International, for instance, illustrate this collaboration with not-for-profit organisations. With regard to SDG Target 16.9, Plan International emphasises innovations in birth registration. Through its 'Count Every Child' initiative, Plan International has helped register '40 million children and influenced laws in 10 countries so 153 million more can enjoy the right to a birth certificate. ${ }^{36}$ Plan is searching for innovative ways to increase birth registration rates and extend registration to the most marginalised.

36 See Plan International, 'Birth registration' < https://plan-international.org/early-childhood/ birth-registration> accessed 15 April 2021. 
It stresses the potential of technology to transform birth registration. ${ }^{37}$ In order to improve civil registration services and to raise awareness in communities about the importance of getting children's births registered, Plan International has called for partnering with a range of stakeholders, such as governments, UN agencies, the private sector, academic institutions, civil society organisations and NGOs ('partner for impact').

In its report 'Innovations in Birth Registration' (2017), Plan International provides guidelines to help define solutions to the most challenging birth registration contexts. It also gives illustrations of birth registration innovations around the world. For instance, in El Salvador, Guatemala, Honduras and Paraguay, the Organization of American States (OAS), together with the civil registries, health ministries and hospital boards, developed a system of effective hospital-based birth registration. Having registration offices in hospitals represents a permanent response to birth registration in the Americas. ${ }^{38}$ For Indonesia, the report refers to the problem that parents are required to show proof of their marriage to be able to obtain a birth certificate for their child that includes the father and mother's name. As a result, many children remained unregistered. The report describes the cooperation between the office of religious affairs (issuing marriage certificates), the religious courts (legalising marriage certificates) and the civil registry offices (issuing birth certificates) through a mobile legal identity service offered at the community level. ${ }^{39}$ In Sierra Leone, due to the Ebola outbreak, the majority of children did not have their births registered. Cooperation between Sierra Leone's Ministry of Health and Sanitation, the WHO, UNICEF and Plan International led to mass birth registration and immunisation services, providing both services in one single movement. ${ }^{40}$

Public-private partnerships for the implementation of SDG Target 16.9 also include collaborations with the private, profit-making industry. Some initiatives are dedicated to the civil registration of vital events. For instance, in Burkina Faso, the government concluded a partnership with iCivil, ${ }^{41}$ a company which developed a mobile technology to facilitate birth registration, particularly in

37 To give one example, in Kenya (Kwale County), a hybrid smart paper technology was piloted in 2018 in an effort to improve maternal and child healthcare as well as birth registration. Children are registered electronically. As a result, health workers stop using the existing manual system. See Plan International, 'Technology improves birth registration and health services' <https://plan-international.org/case-studies/new-technology-improves-birth-registrationand-health-services> accessed 15 April 2021.

38 Plan International and Accenture, Innovations in Birth Registration (16 October 2017) 24 $<$ https://plan-international.org/publications/innovations-birth-registration> accessed 15 April 2021.

ibid 14.

ibid 16.

See for further information, <https://icivil.org> accessed 15 April 2021. 
rural areas where birth registration rates remain low. The technology is based on a digital bracelet for new-born babies, combined with a mobile phone app, through which the health professionals transfer the information to the government's iCivil server. The registration details are then forwarded to the national birth registry. The digital bracelet is kept by the parents and can be used to obtain official documents, as well as to complete the registration if all the required information had not been provided by the parents at birth. Such flexibility allows cultural or religious traditions to be taken into consideration, for instance with respect to the choice of the child's name, which may be made only at a later stage. The contractual model iCivil is proposing is based on a licensing agreement with the government. The concept takes sustainable development into consideration, even beyond SDG Target 16.9, as it promotes a 'made in Africa' solution, based on economic and social inclusion and the respect for local traditions.

However, this is not the most widespread form of collaboration with private businesses. The private industry seems predominantly engaged in the security side of legal identity. Businesses producing identity documents and biometric identification systems are increasingly involved in government policies. African states, with the assistance of the IOM, the EU or other organisations, contract with foreign companies specialising in civil status and biometric identification systems, in order to produce biometric ID and voter cards and to build comprehensive identification databases. In particular, following the Valetta Summit of 2015, where the EU decided to cooperate with countries of origin of migrants to address the absence of identification documents, several African countries contracted, with the help of the EU Trust Fund for Africa, with private or semi-public security companies in order to set up biometric-based identification systems and documents. At present, it is not completely clear whether the strong interest of states in such identity management systems based on biometric identifiers is overtaking civil registration systems, or whether the former are being developed to support the latter. In any case, it has become clear that the financial assistance of the EU Trust Fund for Africa is increasingly tied to the EU's desire to stop irregular migration and to conclude agreements with countries of origin for the return of their nationals. ${ }^{42}$ It must be acknowledged that the current international and European call for the strengthening of civil registration systems is not completely free from a post-colonial perspective. Although the best interest of the people directly concerned is obviously the main drive, another motivation behind that call lies in the political priority of

42 Tuuli Raty and Raphael Shilhav, 'The EU Trust Fund for Africa: Trapped between aid policy and migration politics', Oxfam Briefing Paper (January 2020) <https:// oxfamilibrary.openrepository.com/bitstream/handle/10546/620936/bp-eu-trust-fund-afric a-migration-politics-300120-en.pdf $>$ accessed 15 April 2021. 
Western states to combat irregular migration (often from former colonies) based on forged documents. Some of these projects are promoted as contributions to SDG 16, which is highly debatable because they tend to turn legal identity into a security rather than a human rights issue, which makes them far removed from the rights-based focus of SDG Target 16.9. ${ }^{43}$

One example of these projects is Civipol, a private company operating as the technical cooperation operator of the French Ministry of the Interior. In the field of identity, it provides expertise at all stages of civil registry and identity technology. In Senegal, for instance, Civipol worked on a technical assistance project which aimed to strengthen the civil registration system and create a biometric national identity register, including a fingerprint database of the whole population. ${ }^{44}$ The project was funded by the EU Emergency Trust Fund for Africa in the Sahel region and Lake Chad area. Critics point out that, in reality, these kinds of projects seek to identify irregular migrants in order to enable states of destination to return them to their country of origin. ${ }^{45}$ Despite this, they are promoted as a contribution to SDG 16.

Another example, Idemia (previously OT-Morpho), is a private company that produces biometric ID technologies. It has signed a contract with Mauritania, among others, for an integrated system combining citizen identification, production of biometric ID documents and border control. ${ }^{46}$ In its border control component, the system, which is based on facial and digital recognition, aims at improving the management of migration flows, as well as the fight against terrorism and other forms of criminality. Legal identity is addressed through the lens of security and identity control.

These examples illustrate that there is a wide range of public-private partnerships in the field of legal identity and that some of them raise concerns from the perspective of sustainability and development. In particular, many public-private partnerships do not comply with good governance principles. Rather than taking into consideration local actors and traditions in an integrative approach, they often further the expansion of the Western security industry. Moreover, rather than enabling the populations to exercise their rights, they

43 In that sense, see also Mark Akkerman, 'Expanding the fortress. The policies, the profiteers and the people shaped by EU's border externalisation programme' (Transnational Institute and Stop Wapenhandel, May 2018).

44 Civipol, 'Senegal: Technical Assistance To Strengthen The Civil Registration System And The Creation Of A Biometric National Identity Register' <www.civipol.fr/en/print/pdf/ node/160> accessed 15 April 2021.

45 Mark Akkerman, 'Expanding the fortress. The policies, the profiteers and the people shaped by EU's border externalisation programme' (Transnational Institute and Stop Wapenhandel, May 2018), 78-79.

46 See Nathalie Jullien, 'Morpho participe au renouvellement du système d'état civil mauritanien' $<$ www.safran-group.com/fr/media/20100906_morpho-participe-au-renouvellement-du-sys teme-detat-civil-mauritanien> accessed 15 April 2021. 
build on immigration policy-based biases. Finally, sustainability also implies longevity, ${ }^{47}$ which can only be ensured by the state through a state-owned civil registration system. There is no assurance that foreign and/or private funding is sustainable. Therefore, it is doubtful whether the right to legal identity for all can be sufficiently protected in the current operations of transferring the actual registration in the countries of origin from the public civil registry authorities to private or semi-public companies.

\section{SURVEY OF EXISTING PRIVATE INTERNATIONAL LAW METHODS AND TECHNIQUES ON LEGAL IDENTITY}

\subsection{LEGAL IDENTITY IN INTERNATIONAL CONVENTIONS AND EU REGULATIONS ON PRIVATE INTERNATIONAL LAW}

\subsubsection{European Union}

The 2016 EU Regulation on the circulation of public documents ${ }^{48}$ provides a simplified circulation system for public documents issued by the authorities of a Member State that have to be presented to the authorities of another Member State. It builds on the principle of mutual trust and the assumption that equivalent legal guarantees exist in all EU Member States. The scope of the Regulation comprises civil status documents concerning birth, a person being alive, death, name, marriage, divorce, registered partnership, parenthood, adoption, domicile and/or residence, and nationality. For such public documents, the formalities required for their cross-border circulation are simplified: no legalisation or similar formality is necessary. Regrettably, its scope of application is extremely narrow. The Regulation only provides for the recognition of the instrumentum, not of the negotium those public documents contain. ${ }^{49}$ It is not a Regulation on the recognition of personal status itself, but on the recognition of the public document attesting these civil status events. Moreover, it governs the

47 Term borrowed from Nico Schrijver, 'The evolution of sustainable development in international law: inception, meaning and status' (2007) 329 Collected Courses of The Hague Academy of International Law 217, 369.

48 Regulation (EU) No 2016/1191 of the European Parliament and of the Council of 6 July 2016 on promoting the free movement of citizens by simplifying the requirements for presenting certain public documents in the European Union and amending Regulation (EU) No 1024/2012 [2016] OJ L 200/1.

49 According to Art 2(4), the Regulation does not apply to the recognition of legal effects relating to the content of public documents. 
circulation of such public documents only within the European Union. ${ }^{50}$ And finally, it presupposes the existence of reliable public documents attesting the civil status of a person, whereas SDG Target 16.9 mainly deals with situations where (reliable) public documents do not yet exist.

In a global migration context, the Regulation nevertheless plays a certain role, especially for civil status events that occurred in an EU state of transit. For instance, children born in a refugee camp in Greece, who have their birth registered there, benefit from the Regulation when presenting their Greek birth certificate in Belgium or France. Moreover, the Regulation has potential for future policy developments. Indeed, one possible form of action could lie in the development of registration capacities in EU countries of first arrival of migrants, with a view not only to addressing vital events occurring there, but also to providing supplementary solutions for migrants born in a third country and lacking adequate civil status documents. ${ }^{51}$

\subsubsection{International Commission on Civil Status}

The International Commission on Civil Status (ICCS) aims at facilitating international cooperation in civil status matters. At first sight, it appears to be a highly relevant intergovernmental organisation for the implementation of SDG Target 16.9. Unfortunately, only a small - and constantly decreasing - number of states are party to it, which limits, if not annihilates, its actual contribution. ${ }^{52}$ Moreover, states of origin of migrants are often not party to the ICCS, and even between European states, several potentially interesting conventions never entered into force due to the lack of ratification.

Some matters covered by the work of the ICCS are of importance for SDG Target 16.9, such as the 1985 Convention on the international cooperation in the matter of administrative assistance to refugees. It was designed to complement the 1951 Geneva Convention relating to the status of refugees. According to Article 25 of the Geneva Convention, the authorities of the state in whose territory the refugee is residing shall deliver such documents or certifications as would normally be delivered by the national authorities to whom the refugee

50 According to Art 2(3) a, the Regulation does not apply to public documents issued by the authorities of a third country; since 1 January 2021 the Regulation no longer applies to the UK, which has thus become such 'a third country'.

51 See also GEDIP, 'Declaration on the Legal Status of Applicants for International Protection from Third Countries to the European Union' (September 2015) <www.gedip-egpil.eu/ documents/gedip-documents-25bis.htm> accessed 15 April 2021.

52 See Sabine Corneloup, 'Sur le Groupe européen de droit international privé: Recommandation concernant le maintien et le développement de la coopération internationale en matière détat civil, adoptée le 14 septembre 2019 à Katowice' (2019) 4 Revue critique de droit international privé 1109; Hans van Loon, 'Requiem or Transformation? Perspectives for the CIEC/ICCS and its work' (2018-2019) 20 Yearbook of Private International Law 73. 
can no longer have recourse. These documents replace the official instrument issued by the national authorities, and they shall be given credence in the absence of proof to the contrary. The 1985 ICCS Convention provides for international administrative cooperation in order to determine the identity and civil status of refugees. More precisely, the state in which the refugee resides and which is responsible for the application of Article 25 of the Geneva Convention can contact a state in which the refugee has previously resided, in order to obtain information on the identity and civil status under which the refugee was admitted to or registered in that state. ${ }^{53}$ The 1985 Convention furthermore exempts documents emanating from the state of origin from any legalisation or equivalent formality. ${ }^{54}$

Other ICCS conventions, such as the 1997 Convention on the international exchange of information relating to civil status, or the 1999 Convention on the issue of a certificate of nationality, could also be of paramount importance for the legal identity of migrants. They facilitate the cooperation between national authorities, including civil registrars, in particular for the collection of information relating to identity and civil status. Regarding the evidential weight granted to foreign civil status documents, these conventions rely on the principle that public documents drawn up in conformity with the convention are recognised and shall be accepted as correct, unless and until the contrary is proved. ${ }^{55}$ Furthermore, there is also the successful 1976 Convention on the issue of multilingual extracts from civil status records, which imposes an obligation on contracting states to issue multilingual extracts from records concerning birth, marriage or death, with no need for legalisation or any other formality. This Convention on the promotion of the circulation of civil status documents, together with the more modern 2014 Convention on the issue of multilingual and coded extracts and certificates from civil status records, served as a model for the abovementioned 2016 EU Regulation.

As with the public documents Regulation, the main concern is that all these ICCS conventions presuppose the existence of reliable civil status documents. Moreover, these conventions can only apply between contracting states and therefore depend on the number of ratifications and thus on the political will of states, which is fading even among European countries.

\subsubsection{Hague Conference on Private International Law}

In its Strategic Plan 2019-2022, the Hague Conference on Private International Law stresses that its work, which aims to improve global governance and to

\footnotetext{
53 Art 1(1) Convention on International Cooperation in the Matter of Administrative Assistance to refugees (adopted 3 September 1985).

54 Art 8 of the 1985 Convention.

55 See Arts 4 and 5 of the Convention on the issue of a certificate of nationality (adopted 14 September 1999).
} 
strengthen the rule of law, may be connected to the UN SDGs in general. ${ }^{56}$ Efforts are currently being made by the Permanent Bureau to promote further cooperation with the United Nations. To that end, an information document on 'The HCCH and the United Nations Sustainable Development Goals' was prepared for the Council on General Affairs and Policy of March 2020.57 In terms of content, this document refers, on the one hand, to SDG 16, with a particular focus on the rule of law and access to justice and, on the other hand, to SDG 17, which aims to strengthen means of implementation and revitalise the global partnership for sustainable development. ${ }^{58}$ So far, however, no initiative for further action has been taken with respect to issues concerning the legal identity and civil status documents of migrants. Nevertheless, some existing conventions are linked to it, or provide interesting methodologies or techniques which could be further developed with respect to SDG Target 16.9.

In particular, the 1961 Apostille Convention facilitates the circulation of public documents among states parties through the replacement of the long and costly legalisation process with the issuance of a single apostille certificate. The Convention has become one of the most widely applied multilateral treaties in the area of legal cooperation. ${ }^{59}$

According to the 1978 Convention on the celebration and the recognition of the validity of marriages, a marriage validly celebrated in one contracting state is recognised in all other contracting states. It thereby allows the cross-border mobility of spouses without exposing them to the risk of loss of their marital status. Where a marriage certificate has been issued by a competent authority, the marriage shall be presumed to be valid, until otherwise established. In theory, this could be relevant, for instance, for family reunification of migrants, allowing them to prove the existence and validity of their marriage, but the Convention only entered into force between Australia, Luxembourg and the Netherlands. ${ }^{60}$

The 1996 Convention on the protection of children deals with parental responsibility under both private and public law. It does not apply to matters

56 Hague Conference on Private International Law, 'Strategic Plan 2019-2022' (2019) 5 <www. hcch.net/en/governance/strategic-plan1> accessed 15 April 2021.

57 Permanent Bureau of the Hague Conference on Private International Law, 'The HCCH and the United Nations Sustainable Development Goals' (January 2020) <https://assets.hcch.net/ docs/b5770a41-afef-4118-a2a9-39f939d4d832.pdf> accessed 16 April 2021.

58 The document of January 2020 was not further elaborated in the Council on General Affairs and Policy, 'Conclusions and Decisions adopted by the Council on General Affairs and Policy' (3-6 March 2020) <https://assets.hcch.net/docs/70458042-f771-4e94-9c56-df3257a1e5ff. pdf $>$ accessed 16 April 2021. The Council just 'noted the report of the PB in relation to ... the United Nations Sustainable Development Goals (SDGs), in particular SDG 16, to further the Strategic Priorities of the HCCH': para 56.

59 See <www.hcch.net/en/instruments/conventions/specialised-sections/apostille $>$ accessed 16 April 2021.

60 See <www.hcch.net/en/instruments/conventions/status-table/?cid=88> accessed 16 April 2021. 
of civil status, nor to decisions on the right of asylum and on immigration. ${ }^{61}$ However, issues of parental responsibility or measures for the protection of children are not excluded from its scope of application for the mere fact that they arise in a context of asylum or immigration. ${ }^{62}$ According to the explanatory report of Paul Lagarde, the exclusion applies to decisions which derive from the sovereign power of states. Therefore, only decisions granting or denying asylum or residence permits are excluded, whereas the protection and representation of children who are applying for asylum or for a residence permit fall within the scope of the Convention. ${ }^{63}$ This refers to the traditional 'public law taboo', which is an important challenge for SDG Target 16.9, to which we will return in section 4 .

In order to facilitate the cross-border proof of the capacity in which a person is entitled to act on behalf of a child and of the powers conferred upon him or her, a certificate can be requested from the authorities of the state where a protective measure has been taken or where the child is habitually resident. ${ }^{64}$ The capacity and powers indicated in the certificate are presumed to be vested in that person, in the absence of proof to the contrary. This mechanism constitutes an efficient tool allowing foreign authorities to easily ascertain the capacity and powers of parents and other caregivers. Its extension to legal identity would significantly contribute to SDG Target 16.9.

More generally, the Convention provides a practical mechanism for cross-border cooperation to protect children, mainly through central authorities to be designated by each contracting state. The potential of this private international law instrument and the role of these central authorities for the protection of unaccompanied refugee children is currently under-exploited. ${ }^{65}$ The central authorities of EU Member States do not yet cooperate, for instance, to gather information on the backgrounds of refugee and migrant children or to see if family members can be located or to exchange information in the event a guardian is appointed. At present, the central authorities of EU Member States

61 Convention on Jurisdiction, Applicable Law, Recognition, Enforcement and Co-operation in Respect of Parental Responsibility and Measures for the Protection of Children (adopted 19 October 1996), Art 4(j).

62 Sabine Corneloup et al, 'Children on the move: A private international law perspective' (June 2017, PE 583.158) para 1.1.

63 Paul Lagarde, 'Explanatory Report on the 1996 Hague Child Protection Convention' in Proceedings of the Eighteenth Session (vol II 1996) para 36.

64 Art 40 of the 1996 Convention on the Protection of Children.

65 See our two studies for the European Parliament (JURI Committee): Sabine Corneloup et al, 'Children on the move: A Private international law perspective' (June 2017, PE 583.158); Sabine Corneloup (coord)-et al, 'Private international law in a context of increasing international mobility: Challenges and potential' (June 2017, PE 583.157). 
tend to give priority to their national asylum counterparts that are in charge of the implementation of the Dublin Regulation. ${ }^{66}$

Furthermore, there is the 1993 Hague Convention on International Child Adoption. Although this Convention does not deal with legal identity itself, identity is central to the matching mechanism. Moreover, it contains a provision concerning the identity of the child's biological parents. The authorities of the child's country of origin shall ensure that such information, if held by them, is preserved and that the child has access to it, insofar as is permitted by its law. ${ }^{67}$ Moreover, the Convention also deals with the migratory status of the child in the country of the prospective adoptive parents. Cooperation between the central authorities of the state of origin of the child and the state of residence of the adoptive parents ensures that the adoption can only take place once it has been determined that the child is authorised to enter and reside permanently in the receiving state. ${ }^{68}$

\subsection{LEGAL IDENTITY AT THE NATIONAL PRIVATE INTERNATIONAL LAW LEVEL}

\subsubsection{Private International Law Assumptions and Objectives}

This is not the place for an in-depth presentation of the objectives and assumptions of private international law. ${ }^{69}$ However, it is worthwhile to recall that, concerning personal and family status, the fundamental objective is to guarantee the permanence of legal identity and to avoid limping situations, in which the personal or family identity of an individual is considered lawful and valid in one legal order, but not in another. Cross-border mobility in general, and migration in particular, must not lead to a loss of the legal (personal and family)

66 Regulation (EU) No 604/2013 of the European Parliament and of the Council of 26 June 2013 establishing the criteria and mechanisms for determining the Member State responsible for examining an application for international protection lodged in one of the Member States by a third-country national or a stateless person (recast) [2013] OJ L 180/31.

67 Convention on Protection of Children and Co-operation in Respect of Intercountry Adoption (adopted 29 May 1993), Arts 16(1)(a) and 30.

68 Arts 17(d) and 18 of the 1993 Hague Convention.

69 See recently, among others, Ralf Michaels, 'Private International Law and the Question of Universal Values' in Franco Ferrari and Diego P Fernández Arroyo (eds), Private International Law. Contemporary Challenges and Continuing Relevance (Edward Elgar Publishing 2019) 148; Horatia Muir Watt, 'Discours sur les méthodes du droit international privé (Des formes juridiques de l'inter-altérité)' (2018) 389 Collected Courses of the Hague Academy of International Law 9; Yves Lequette, 'Les mutations du droit international privé : vers un changement de paradigme?' (2016) 387 Collected Courses of the Hague Academy of International Law 9. 
identity of the person. The achievement of this objective requires a prima facie attitude of openness towards foreign legal orders, which is not made conditional upon the content of their laws.

However, one must also keep in mind that, historically, private international law rules were conceived on the assumption that the conflicts between national legal orders involve equal, like-minded and similarly developed states on both sides. Thereby, traditional private international law rules address legal identity from the perspective of the cultural background of Western industrialised states. With respect to (the proof of) legal identity, that approach results in attaching high value to dates and documents and in taking a reliable public civil registry for personal status events for granted, which objectively is not the situation worldwide. A gap exists between the assumptions of private international law and the actual nature of the conflicts between legal orders in matters relating to personal status on a global level.

When that gap between private international law assumptions and the global reality becomes too wide, and in addition restrictive migration policies interfere, private international law methods and techniques are deemed (even if only implicitly) inappropriate and are either adapted or not applied in practice.

\subsubsection{Private International Law Methods and Techniques}

In a cross-border situation, the legal identity of a person can give rise to several questions that fall into different private international law categories. According to the European tradition, legal identity belongs to the category of personal status. Within the matter of personal status, several conflict rules coexist under national private international law, requiring that each issue linked to legal identity be characterised, in order to identify the corresponding conflict rule. In this respect, a fundamental distinction is made between the validity of a legal relationship, on the one hand (section 3.2.2.2), and the proof thereof, on the other hand (section 3.2.2.3). Usually, the difficulties that arise when the migration status of the person is not at stake relate to the existence and validity of the legal situation. In practice, the proof of that status rarely is the main difficulty. By contrast, in situations where the migration status of a person depends on his or her personal and family identity, proof becomes the most important hurdle. ${ }^{70}$ Below, parentage and marriage will serve as examples to illustrate how national private international law methods and techniques in two European countries operate in migration-independent situations, as well as in migration-related situations. But first, a broader perspective is taken in order to shed some light on

70 See more generally on the recognition, in a migration context, of personal status acquired abroad our Study for the European Parliament (JURI Committee): Sabine Corneloup et al, 'Private international law in a context of increasing international mobility: Challenges and potential' (June 2017, PE 583. 157). 
the causes, explaining that validity and proof do not have the same importance for the two kinds of situations (section 3.2.2.1).

\subsubsection{The Rise of Evidentiary Issues in Migration-Related Situations}

The explanation behind the major difference between migration-related and migration-independent situations lies in the law, namely in the international and European law on human rights and refugee protection. Indeed, paradoxically, human rights and the right to asylum are a major cause of the importance the evidence of legal identity has gained over the past decades. This is of course not to say that human rights and refugee law should be criticised. However, it is important to acknowledge that these rights protected under international and European law may, in practice, have unintended side-effects. Analysing, among others, the categories of residence permits issued by France to non-European migrants between 2005 and 2017, the French sociologist François Héran stresses the significant proportion of rights-based migration, perceived as migration subie, compared to labour migration, often called migration choisie. ${ }^{71}$ In 2017 , of a total of 240,000 residence permits issued by French authorities, only 25,000 were labour-related, whereas 88,000 residence permits were issued to non-EU family members of French citizens and of foreign citizens legally residing in France. This family-based migration is a result of the recognition, under migration law, of the fundamental right to family life as enshrined in particular in Article 8 of the European Convention on Human Rights and Article 7 of the EU Charter of Fundamental Rights. In addition, 36,000 residence permits were issued to refugees and for health reasons, as a consequence of international and European refugee law (the principle of non-refoulement) and fundamental rights, which brings the total of rights-based migration to more than 50 per cent of the residence permits issued to non-EU migrants. ${ }^{72}$

In the political context that has dominated the migration policies of several states of destination over recent decades, governments wishing to reduce the number of migrants on their territory realised that they will have little impact on those rights-based residence permits so long as they do not want to denounce their international and European commitments. A legally valid marriage or parent-child relationship creates rights. Likewise, a specific nationality and

71 François Héran, Avec l'immigration - Mesurer, débattre, agir (La Découverte 2017); see also his lectures on 'Migrations et sociétés' at the Collège de France, and in particular the 2018-2019 course on 'Pourquoi migrer?' <www.college-de-france.fr/site/francois-heran/ course-2017-2018.htm> accessed 16 April 2021.

72 Figures of the French Ministry of Interior, AGDREF Database (Application de gestion des dossiers des ressortissants étrangers en France), quoted by François Héran in his lectures of 10 January 2019 at the Collège de France (see previous footnote). Another important category of non-EU beneficiaries of residence permits are students $(79,000$ residence permits in 2017). 
region of origin may entitle a refugee to international protection. ${ }^{73}$ The only way not to recognise such rights is to challenge the existence of the legal relationship at their very source. Challenging the evidence of legal identity becomes one of the main legal levers for authorities wishing to reduce the numbers of migrants. Hence, even if the widespread suspicion of fraud is partly well founded, given the significance and reality of all kinds of irregularities, it is also a strategy to avoid the obligation to issue a residence permit to a migrant who would be entitled to it. For instance, the family of a migrant who holds a residence permit is entitled to family reunification on the grounds of parentage and marriage. Where the validity of the family relationship is not questionable in itself, the fundamental right to family life obliges the state to grant the family reunification, unless it is argued that there is insufficient evidence of the existence of the marriage or the parent-child relationship.

With this difference between migration-related and migration-independent situations in mind, the summa divisio between validity and proof of personal and family status will now be further explored.

\subsubsection{Validity of the Legal Situation of a Person}

\subsection{General Private International Law Methods and Techniques}

To take an example, if the succession rights of a child depend on the validity of the parent-child relationship between the child and the deceased, two different methods are applied in private international law depending on how parentage is established. Parentage by law or by recognition of paternity is addressed through choice-of-law rules, whereas parentage established by judgment is subject to rules on the recognition of foreign judgments. Both methods contain a public policy exception and both methods may require techniques of transposition and adaptation, if the foreign legal concept is unknown in the forum.

Regarding parentage by law or by recognition of paternity, first of all, the connecting factor used by the choice-of-law rule may differ from one country to another (nationality, domicile, habitual residence), but the overall methods and techniques are the same. For instance, parentage by law is governed in French private international law by the law of the state of the mother's nationality. ${ }^{74}$ Recognition of paternity or maternity is valid, according to French private international law, if it complies either with the law of the state of the man's or

73 In particular, with respect to subsidiary protection under Art 15(c) of the Qualification Directive 2011/95/EU of the European Parliament and of the Council of 13 December 2011 on standards for the qualification of third-country nationals or stateless persons as beneficiaries of international protection, for a uniform status for refugees or for persons eligible for subsidiary protection, and for the content of the protection granted (recast) [2011] OJ L 337/9.

74 Art 311-14 of the French Civil Code. 
woman's nationality, or with the law of the state of the child's nationality. ${ }^{75}$ In Belgium, both parentage by law and recognition of paternity or maternity are governed by the law of the state of nationality of the person whose maternity or paternity is at stake. ${ }^{76}$

If the choice-of-law rule designates a foreign law the application of which would lead to a result which is manifestly incompatible with the fundamental principles of the forum, that law shall not be applied (public policy exception). In migration-independent as well as in migration-related situations, it is likely, for instance, that a foreign law that prohibits establishing legal paternity if the father and the mother are not married would be declared incompatible with the public policy of these European states. ${ }^{77}$

Secondly, if parentage is established by way of a foreign court decision, the permanence of personal status is achieved through the private international law rules on the recognition of foreign judgments. In several countries, those private international law rules are characterised by their openness and flexibility. The smooth recognition of judgments expresses private international law's fundamental objective to facilitate cross-border continuity and to avoid 'limping' situations. Of the requirements that may differ from one state to another, a common ground for refusal of recognition is the manifest incompatibility of the decision with the public policy of the requested state. In this context, public policy is understood in a very narrow sense, since the legal situation was created by a court decision in a foreign country.

In order to coordinate the coexistence of different legal orders in an individual case, private international law techniques such as transposition and adaptation fine-tune the mechanics of the general conflicts methodology. For instance, a foreign decision on the adoption of a child may require transposition into the categories of the forum distinguishing between full and simple adoptions depending on whether pre-existing legal parent-child ties are severed. ${ }^{78}$ In a migration context, this can become relevant as regards migrants' access to the nationality of the state of residence, when nationality law provides simplified rules for full adoptions. ${ }^{79}$ Another well-known example is the Muslim institution

Art 311-17 of the French Civil Code.

Art 62 of the Belgian Code of Private International Law.

At least, this has been the consistent position of the French Cour de cassation since Cass civ 1, 10 February 1993, no 89-21997. For a discussion on Belgian case law, see Hélène Englert and Jinske Verhellen, 'Lapplication du droit marocain de la famille en Belgique 2004-2015' in Marie-Claire Foblets (ed), Le Code marocain de la famille en Europe. Bilan de dix ans d'application (LGDJ/la Charte 2016) 327-330; Patrick Wautelet, Relations Internationales. L'actualité vue par la pratique (Anthemis 2010) 132-137; Patrick Wautelet, 'Ordre public international et filiation hors mariage' (2008) 19 Revue de Jurisprudence de Liège, Mons et Bruxelles 822, 835 .

78 See, for instance, Arts 370-4 and 370-5 of the French Civil Code.

79 See for instance in France, Art 20 (full adoptions) and Art 21 combined with Art 21-12 (simple adoptions) of the Civil Code. 
of kafala, which shall not be transposed into parentage because the institution has been specifically established as an alternative to adoption, which is prohibited by several Muslim countries. The relationship between the kafils and the makful cannot trigger the application of rules which are premised on the existence of a parent-child relationship. This holds true under civil law, as well as under migration law. The Court of Justice of the European Union has decided, with respect to entry and residence rights according to the Citizens Directive 2004/38, that a child placed under the Algerian kafala system is not a 'direct descendant' of a citizen of the Union, but falls under the category of 'other family members. ${ }^{80}$

In general, these private international law rules potentially guarantee the cross-border continuity and permanence of the personal and family status of migrants. It is the proof of parentage or marriage that gives rise to difficulties (see section 3.2.2.3), whereas problems are relatively rare at the level of validity, with the notable exception however of sham marriages and sham recognition of paternity or maternity.

\subsection{Fraud-Related Provisions on Sham Legal Relationships}

Visa or residence permits, or access to nationality, may be denied where authorities suspect misuse of the right to family reunification. For instance, paternity established abroad is not recognised, because the acknowledgment or adoption of a child is seen as a way of evading nationality or migration law. Recognition is not refused on the ground that there would be validity problems in terms of the applicable foreign law, but because of suspicion of fraud.

Sham legal relationships can be addressed through traditional private international law techniques, such as the public policy exception, which may apply within the choice-of-law reasoning, or obstacles to the recognition of a foreign judgment. ${ }^{81}$ In addition to these traditional techniques, in several European countries recent legislative changes to substantive law have given a larger role to the law of the forum. This predominance of states' own national law is justified by the concern of avoiding fraudulent situations, such as marriages of convenience, ${ }^{82}$ sham adoptions ${ }^{83}$ or sham recognitions of children. ${ }^{84}$

In Belgium, the recent legislation on sham acknowledgements of children ${ }^{85}$ adds another layer by explicitly muting the abovementioned choice-of-law rules

80 Case C-129/18 SM v Entry Clearance Officer, UK Visa section [2019] ECLI:EU:C:2019:248. See also, ECHR Chbihi Loudoudi v Belgium App no 52265/10 (16 December 2014); ECHR Harroudj v France App no 43631/09 (4 October 2012).

81 See for a recent illustration in France with respect to a foreign adoption: Cass civ. 1, 15 January 2020, no 18-24261, requiring the motivations of the adoptant to be assessed.

82 See, for instance, Art 146bis of the Belgian Civil Code.

83 See, for instance, Art 365-2 of the Belgian Civil Code.

84 See, for instance, Art 330/1 of the Belgian Civil Code.

85 Act of 19 September 2017, Moniteur belge 4 October 2017. 
and introducing a mandatory rule. ${ }^{86}$ Belgian substantive law must be applied each time the establishment of parentage results in a residence permit for at least one of the parties, even if, on the basis of the choice-of-law rules, the applicable law is not Belgian law. Under French law, a marriage celebrated by a French spouse in a foreign country is subject to specific formalities aiming at ascertaining the genuine consent of the spouses. Among others, the spouses are interviewed in order to prevent or sanction sham marriages. ${ }^{87}$ Moreover, the requirement of consent to marriage, according to French civil law, applies as an overriding mandatory provision even to the spouse who holds a foreign nationality ${ }^{88}$ This allows a sham marriage to be declared null and void, even if genuine consent is not required for the marriage to be valid according to the law of the spouse's nationality.

Hence, for migration-related situations, specific internationally mandatory provisions on the consent to marry, the recognition of a child, etc. provide derogating solutions. The general private international law assessment, characterised by openness towards foreign legal orders, is no longer deemed necessary or relevant.

\subsubsection{Proof of the Legal Situation of a Person}

The primary means of proof for facts and acts related to personal and family status are civil status documents, such as birth, marriage and death certificates issued by the authorities that are responsible for civil status registration in the country where these facts and acts took place. Private international law provides rules for the recognition of such civil status documents in a cross-border context. The submission of a document, however, is a significant challenge for many migrants and the very hurdle SDG Target 16.9 addresses.

In the current political context, when it comes to evidence, there is a big difference between migration-independent and migration-related situations. Below both situations will be compared for civil status acts (section 3.2.2.3.1), supplementary judgments (section 3.2.2.3.2) and age assessment and DNA procedures (section 3.2.2.3.3).

\subsection{Foreign Civil Status Acts}

According to private international law characterisations, the admissibility of modes of proof is governed by the lex fori. This law also determines the probative value of each means of proof. However, the modes admitted by the lex loci

\footnotetext{
86 Circular of 21 March 2018, Moniteur belge 26 March 2018.

87 Art 171-2 Civil Code. Sabine Corneloup, 'Maîtrise de l'immigration et célébration du mariage' in Mélanges en l’honneur de Paul Lagarde (Dalloz 2005) 207.

88 Art 202-1 French Civil Code.
} 
actus are often accepted as well, especially with a view to protecting legitimate expectations of the parties. Exceptionally, in some areas, such as parentage, where the link between proof and substance is particularly strong, the private international law classification results in lex causae being designated, rather than the lex fori ${ }^{89}$ For example, according to Article 47 of the French Civil Code, full faith must in principle be given to acts of civil status made in a foreign country and drawn up in the forms in use in that country. ${ }^{90}$ This is not a traditional choice-of-law rule but a substantive provision, into which a choice-of-law reasoning is incorporated as a precondition. The form of the act is governed by the lex loci actus and, according to the principle of auctor regit actum, foreign public authorities operate according to the law of their own states. Article 47 defines the legal effects of those documents, and in particular their probative value. The rule works perfectly well in migration-independent situations, when for instance an Australian child claims succession rights in France on the basis of an Australian birth certificate establishing the existence of a parent-child relationship with the deceased. If the foreign birth certificate is legalised/apostilled, ${ }^{91}$ full faith will be given in France to this civil status document established by an Australian authority in conformity with Australian law.

However, Article 47 not only creates a presumption of probative value but also defines the limits thereof, by providing that full faith is not given when other records or documents retained, external evidence, or elements drawn from the act itself establish, after all useful verifications if necessary, that the act is irregular or forged, or that the facts declared therein do not square with the truth. These limits were introduced into Article 47 by legislative acts of 2003 and 2006, the main subjects of which were immigration, access to nationality and the scrutiny of the validity of marriages celebrated abroad. The political motivation of the legislators was to fight against documentary fraud in a migration context. Today, an attitude of suspicion of fraud has taken hold of nearly all public authorities.

89 See for parentage Cass, 24 May 2018, no 16-21163 in France. Or giving the choice between the lex causae and the lex loci actus, see Art 63 of the Belgian Code of Private International Law.

90 See, inter alia, Christine Bidaud, 'La transcription des actes de l'état civil étrangers sur les registres français: Cesser de déformer et enfin réformer ...' (2020) 2 Revue critique de droit internationale privé 247; Sabine Corneloup, 'Larticle 47 du Code civil et le droit international privé' (2020) 20 Revue de droit d'Assas 101; Christine Bidaud, 'Preuve de la nationalité et actes de l'état civil étrangers' in Amélie Dionisi-Peyrusse et al (eds), La nationalité : enjeux et perspectives (Institut Universitaire Varenne 2019) 299; Aurore Camuzat, 'La force probante des actes de l'état civil étrangers' in Hugues Fulchiron (ed), La circulation des personnes et de leur statut dans un monde globalisé (LexisNexis, Perspectives 2019) 311.

91 See the Hague Convention Abolishing the Requirement of Legalisation for Foreign Public Documents (adopted 5 October 1961), to which 118 states are parties, including France and Australia. No probative value is recognised if the requirement of legalisation or apostille is not met. For a recent re-affirmation of that principle, see Cass, 16 October 2019, no 19-16353. This is to be criticised because the foreign certificate could at least have an 'effet de fait' and serve as a de facto presumption, to be completed by other means of proof. 
A consultation on Legifrance ${ }^{92}$ of the decisions rendered by the French Cour de cassation in 2019 gives an idea of the typical factual background of the cases falling under Article 47 in migration-related situations: the French authorities generally claim that the civil status documents presented by the person concerned are irregular or forged, and the latter has no alternative reliable means of proof of his legal identity in his or her possession. Migrants from countries whose civil status certificates are notoriously unreliable are today facing systematic suspicion of fraud in Europe. In migration-independent situations, by contrast, these limits are rarely applied, with the notable exception of surrogate motherhood.

\subsection{SUPPLEMENTARY JUdGMENTS}

In some countries, it is possible to have recourse to supplementary judgments if civil status documents are missing or not authentic. Most widely known are the declaratory judgments in lieu of birth certificates. Such judgments are generally rendered in the country where the fact or act relating civil status took place. Such procedures for missing birth certificates and, by extension, also for late or delayed birth registration could support the implementation of SDG Target 16.9.

According to private international law rules on the recognition of foreign judgments, these supplementary judgments are to be recognised like any other foreign judgment. In different European states, such as France and Belgium, which take a liberal approach even to decisions from non-EU states, this alternative means of proof of legal identity raises no major difficulty, as long as the situation is migration-independent. By contrast, in migration-related situations, the suspicion of fraud affects supplementary judgments in the same way as it affects civil status certificates. The judgment is not recognised if its authenticity is doubtful or, more generally, if the state of origin of the judgment is blacklisted. Here again, in practice, the (real or alleged) unreliability of a foreign legal system results in the general rules and methods of private international law being set aside.

\subsection{Age Assessment and DNA Testing}

Another example is age assessment procedures for migrant children. In general, the proof of the age of a child is rarely, if ever, an issue with which private international law has to deal. In migration-independent situations, difficulties arise only with respect to the actual implementation of the rules on parental responsibility and international child protection. The actual applicability of those rules is not questioned, whereas in migration-related situations the opposite is true. Indeed, migrant children in general, and unaccompanied

92 <www.legifrance.gouv.fr/> accessed 16 April 2021. 
migrant children in particular, benefit from more favourable derogating provisions under migration and asylum law. As most unaccompanied minors are between 15 and 17 years old, doubts may exist regarding their age. Here again, fraud is (often systematically) suspected. Many European states have developed specific age assessment procedures, based on interviews with the child and/or medical examinations and bone tests. ${ }^{93}$ According to EU asylum law, minority is presumed when, after exploring all the age assessment methods available, it is not possible to determine the child's age with sufficient certainty. ${ }^{94}$ In practice, however, the presumption is not effectively applied in all Member States, since authorities tend to easily conclude that the child is over the age of majority. Numerous court decisions and decisions of administrative authorities bear witness to that attitude. Instead of focusing on access to protection as a minor, the boy or the girl will be scrutinised as a possible liar about his or her age. In this context, private international law methods and techniques are simply deactivated. Even if the child has documentary proof of his or her minority and the private international law rules on the recognition of civil status acts should apply, other invasive (medical) age assessment procedures often take over. There is no principle of giving the benefit of the doubt to the child. ${ }^{95}$

The same can be said about family reunification files in which migration authorities in the states of destination resort to genetic paternity/maternity tests even though this is not in accordance with the rules on parentage in their substantive family law (for instance because a man can acknowledge a child even in the absence of biological affiliation) or even if the persons concerned present civil status documents (e.g. late or delayed declaration of birth by means of a supplementary judgment).

93 For a comparative overview, see our Studies for the European Parliament (JURI Committee): Sabine Corneloup (cord) -et al, 'Private international law in a context of increasing international mobility: Challenges and potential' (June 2017, PE 583. 157), para 1.2.1.4; Sabine Corneloup (coerdet al, 'Children on the move: A Private international law perspective' (June 2017, PE 583.158), para 3.3.

94 Art 25(5) of the Procedures Directive 2013/32/EU of the European Parliament and of the Council of 26 June 2013 on common procedures for granting and withdrawing international protection [2013] OJ L 180/60.

95 As recommended in UN Committee on the Protection of the Rights of All Migrant Workers and Members of Their Families, 'Joint General Comment No 4 (2017) of the Committee on the Protection of the Rights of All Migrant Workers and Members of Their Families and No 23 (2017) of the Committee on the Rights of the Child on State obligations regarding the human rights of children in the context of international migration in countries of origin, transit, destination and return', UN Doc CMW/C/GC/4-CRC/C/GC/23 (16 November 2017) para 4. See also EASO, 'EASO Practical Guide on Age Assessment' (2018) 22-25 <www.easo.europa.eu/ news-events/easo-publishes-practical-guide-age-assessment> accessed 16 April 2021; UNHCR and UNICEF, 'The Way Forward to Strengthened Policies and Practices for Unaccompanied and Separated Children in Europe' (10 July 2017) 9. 


\section{POTENTIAL OF THE SDG FRAMEWORK TO SPUR NEW THINKING ON LEGAL IDENTITY IN PRIVATE INTERNATIONAL LAW}

The previous section does not leave much room for optimism. Private international law, or the private side of legal identity in a migratory context, seems to have been set aside.

At the global level, the abovementioned initiatives seem to signal that there is political will to address legal identity issues from a human rights perspective. These initiatives - even if some are liable to criticism - lead to more birth registration and certification. This evolving new framework under SDG Target 16.9 impacts on international migration too: more births are registered in the states of origin, and more migrants have access to reliable civil status documents, which can be presented to obtain passports and visas, to evidence family ties in the context of family reunification procedures, or to prove one's age as unaccompanied minor. In this emerging scenario, states of destination will have no choice but to take those civil status documents into account, otherwise they will be calling to question the SDG Target 16.9 implementation initiatives themselves.

In this new context of more and better civil registration, the potential of private international law instruments could be unlocked in several ways: (1) by overcoming the public/private law divide in order to effectively address legal identity issues in the current migration context; (2) by revitalising and building on international conventions and EU regulations on private international law; and (3) by disconnecting migration policies from legal identity issues.

\subsection{OVERCOMING THE PUBLIC/PRIVATE LAW DIVIDE IN ORDER TO EFFECTIVELY ADDRESS LEGAL IDENTITY}

With regard to SDG Target 16.9, the UN Legal Identity Task Force cooperates with organisations outside the UN whose mandate is directly or indirectly linked with the holistic approach to legal identity. This could be a concrete gateway for the Hague Conference to take initiatives - in line with its Strategic Plan 2019-2022 - to cooperate with the United Nations and its Legal Identity Agenda 2020-2030. Currently none of the Hague conventions directly address cross-border issues of legal identity, even though it is a central, personal status matter to which several conventions are closely linked. In the context of the new global framework, the fact that legal identity is widely acknowledged to be catalytic for achieving several SDGs should be an incentive to take initiatives.

Taking initiatives with respect to legal identity issues in a migration context would entail the Hague Conference, and by extension private international law 
in general, overcoming the public law taboo. To date, the Hague Conference has pushed aside issues directly or indirectly related to international migration, arguing among others that they involve public law aspects. ${ }^{96}$ However, one of the very purposes of the SDGs is precisely to adopt an integrative approach that reaches beyond disciplinary boundaries. How can legal, social, economic and environmental considerations be integrated, if, within the legal sphere alone, it is not even possible to overcome the public/private law divide? In international law, scholars are increasingly questioning the lines of that divide, which have become blurred over the past decades. ${ }^{97}$ Private international law has been confined to 'a purely ancillary function beyond (or beneath) the international political sphere', from which it has to find a way out, in order to participate 'in the politics of international law' and to 'ensure that interests beyond the state of which some require tethering while others strive for recognition - work towards the planetary good. ${ }^{98}$ This is precisely what is called for to achieve SDG Target 16.9.

As discussed in section 3, several private international law methods and techniques codified in Hague conventions, despite not directly addressing legal identity, have the potential to provide solutions to problems related to international migration, if they were transposed to cross-border recognition of family ties in the context of family reunification or to cross-border cooperation in the field of protection of migrant and refugee children. That potential can only be unlocked if the Member States of the Hague Conference recognise that legal identity (too) is a private law matter and agree to initiate legislative projects in this area, despite the public law implications it has in the context of international migration.

In particular, improved operation of civil registration systems in states of origin, as a consequence of the implementation of SDG Target 16.9, will generate the need for more cooperation between states. Private international law lends itself pre-eminently to such international cooperation and the Hague Conference is very well placed to take initiatives, as it has states of origin, states of transit and states of destination among its Member States. Such initiatives could also support the implementation of SDG Target 16.8 on broadening and strengthening the participation of developing countries in the institutions of global governance. The Hague Conference has longstanding experience with methods and tools of cooperation, in which 'central authorities' play a prominent role. For instance, in

\footnotetext{
96 For instance, with regard to unaccompanied and separated children: Permanent Bureau of the Hague Conference on Private International Law, 'The application of the 1996 Child Protection Convention to unaccompanied and separated children' (February 2020) <https:// assets.hcch.net/docs/64150323-9f1a-4f32-83a8-81558ea75e60.pdf> accessed 16 April 2021.

97 See the collection of foundational texts assembled by Horatia Muir Watt (ed), Private International Law and Public Law (2 volumes, Edward Elgar Publishing 2015).

98 Horatia Muir Watt, 'Private International Law Beyond the Schism' (2011) 2 Transnational Legal Theory 347 (the quotes are from pages 355 and 427).
} 
the case of suspicion of fraud or the lack of any official documents, cooperation between central authorities of the concerned states should be set up, and the authorities of the state of origin should collaborate in investigations and the taking of evidence. ${ }^{99}$ However, the experience of the Hague Conference has also shown that cooperation mechanisms are only effective if the central authorities are properly equipped, which presupposes sufficient financial support from their governments. Consequently, any initiative in this respect must include measures designed to support countries in the Global South.

\subsection{REVITALISING AND BUILDING ON INTERNATIONAL CONVENTIONS AND EU REGULATIONS}

In the light of the new global framework, a possible revitalisation of the conventions adopted by the ICCS deserves serious consideration. As described in section 3, several of the ICCS conventions presuppose the existence of reliable civil status documents. Implementing SDG Target 16.9 precisely meets this prerequisite. Implementing the goal of universal civil registration of all vital life events could revive the ICCS conventions. The very basis for the practical operation of these conventions would then be in place. The evolving new global framework under SDG Target 16.9 could possibly lead to more interest in these conventions and potentially to more ratifications and accessions. Hans van Loon describes the potential relevance of the ICCS conventions in the relations between the current (although decreasing) states parties and other states in Latin America, the Caribbean, the Middle East and Africa, and he goes on to say that 'if ICCS conventions were in force on a global scale, they would support the respect of the right to identity of migrants, and the interoperability of civil registry systems between States of origin (and return), transit States and States of destination.' ${ }^{100}$

A possible initiative for the Hague Conference could build on another recommendation previously formulated by Hans van Loon, namely to include the ICCS conventions when reviewing the practical operation of the Hague conventions: 'Given their complementary role in relation to the Hague Children's Conventions, relevant ICCS Conventions could usefully be included in the agendas of Special Commission meetings on the practical operation of these instruments.'101 Unlike the Hague conventions, the ICCS conventions

\footnotetext{
99 Sabine Corneloup, 'Can Private International Law Contribute to Global Migration Governance?', in Horatia Muir Watt and Diego Fernández Arroyo (eds), Private International Law and Global Governance (OUP, 2014), 316-317.

100 Hans van Loon, 'Requiem or transformation? Perspectives for the CIEC/ICCS and its work', (2018-19) 20 Yearbook of Private International Law 73, 83-84.

$101 \quad$ ibid 91.
} 
deal with a variety of topics relating to legal identity and civil status. However little ratified, the Hague Conference could explicitly support the use of these ICCS conventions and thus put the issue of civil status and legal identity more prominently on its agenda.

Furthermore, it would also be in the spirit of the global SDGs framework to build on the 2016 EU Regulation on the circulation of public documents in order for the Regulation to reach its full potential in a migration context. This Regulation guarantees the circulation of civil status documents between Member States. For migrants lacking reliable documents, the EU could consider possible ways to respond to that lack by developing alternatives in the Member State of first arrival. Reliable documents issued there could then circulate with the migrant across the EU in line with the 2016 Regulation.

\subsection{DISCONNECTING MIGRATION POLICIES FROM LEGAL IDENTITY ISSUES}

In the ideal world of this new global framework in line with SDG Target 16.9, states of destination will be less and less able to challenge the existence and proof of legal identity as a strategy to refuse residence permits or nationality. In migration-related situations, the discussion might shift from evidence to content, from proof to validity. Consequently, existing private international law methods and techniques might regain their role and legal identity issues could be approached in a different way.

However, such a scenario is not yet likely, as we believe that the context of suspicion of fraud is not about to disappear soon. Nevertheless, states will have to adjust their strategy as the implementation of SDG Target 16.9 will leave less room for questioning the evidence and existence of legal identity. Continued practice based on suspicion of fraud will then impact on what Héran calls rights-based migration ${ }^{102}$ and thus on states' international and European human rights commitments. It is unlikely that states will be willing to officially denounce those human rights commitments in order to limit rights-based migration. At the same time, it is also unlikely that states will abandon their restrictive migration policies, once the strategy based on the questioning of evidence is no longer available to the same extent as today. In the current European context, no crystal ball is needed to predict that states will increasingly have recourse to externalisation policies. By preventing migrants from approaching their territories, states can partially deactivate European human rights commitments, as the recent decision of the European Court of Human Rights in M.N. and Others $v$ Belgium illustrates. ${ }^{103}$ In relation to Belgium's refusal to issue a humanitarian

\footnotetext{
102 See above, $\mathrm{n} 74$.

103 ECHR M.N. and Others v Belgium App no 3599/18 (5 May 2020).
} 
visa to a Syrian refugee family who submitted their visa application at the Belgian embassy in Lebanon, the Court ruled on the extraterritorial reach of the ECHR and the territorial delimitation of states' obligations. It concluded by declaring the case inadmissible because Belgium had no jurisdiction over the applicants. Convention rights only apply to persons who find themselves within the jurisdiction of the states parties to the Convention, and, save in exceptional circumstances, jurisdiction is primarily territorial. In a configuration of this kind, private international law does not come into play.

Consequently, SDG Target 16.9 undeniably has the potential to improve the legal situation of migrants, if combined with private international law methods and techniques, by disconnecting migration policies from legal identity issues. If migrants can prove their legal identity, they are empowered to exercise their rights. However, one has to be realistic. As long as the migration policies remain the same, Western states will find other strategies to limit legal access to residence permits and nationality.

\section{CONCLUSION}

The overview in section 3 revealed that, at present, existing private international law conventions and regulations do not have much practical impact, whether because they have not entered into force, do not apply in the relation between states of origin and states of destination of migrants, or do not really address legal identity issues. Moreover, the comparison between migration-independent and migration-related situations from the perspective of proof of legal identity made clear that private international law methods and techniques are not applied in the same way in the two kinds of situations. The current migration context leads to an 'inconvenient truth': one of the fundamental private international law objectives is cross-border continuity and harmony, but because states in the Global North pursue their own specific migration policies rather than seeking cross-border solutions, migration often leads to a discontinuity and even destruction of legal identity and a violation of the right to be recognised as a person before the law. As long as a direct link exists between the migratory status and the civil status of a person and as long as national authorities are guided, with respect to the proof of legal identity, by the suspicion of fraud, private international rules are likely to remain ineffective.

Yet these current deficiencies should not make us lose sight of the potential of private international law. The more comprehensive approach of SDG Target 16.9 indeed creates a new and challenging context. We have formulated three possible avenues through which private international law instruments and methodologies could become more relevant in terms of achieving the substantive targets of SDG 16: (1) by overcoming the public/private law divide in order to effectively address legal identity issues in the current migration context; (2) by revitalising 
and building on existing international conventions and EU regulations on private international law; and (3) by disconnecting migration policies from legal identity issues. In addition, SDG Target 16.9 should go even further. Where it uses birth 'registration' as an indicator, it weakens its ambition: what is birth registration worth if one cannot take it along when crossing borders? Although under a lot of pressure, private international law has something to offer here. Private international law does not operate with indicators that only measure numbers of registrations. It has the potential to guarantee that legal identity is of real value across borders and thus a means to empower migrants to exercise their rights. 